\title{
7. 大学体育の理念一中教㥶中旬報告と関遇して一
}

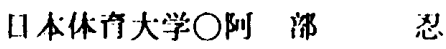

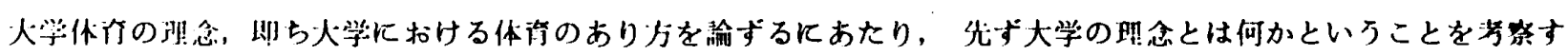

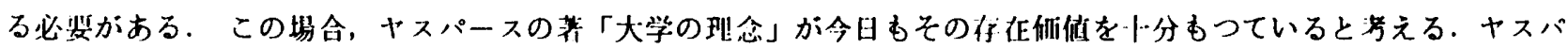

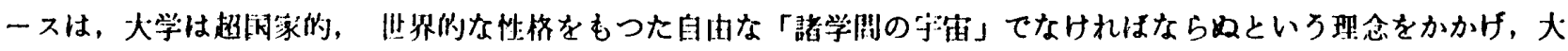

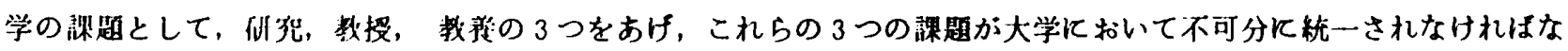
らないという，そして，それらの課题の達成は思考する人々の交沙 (Kommunikation) に結びついていると論して

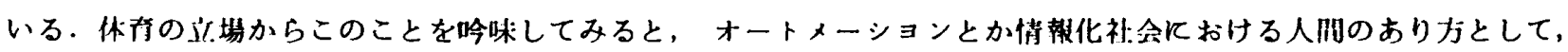

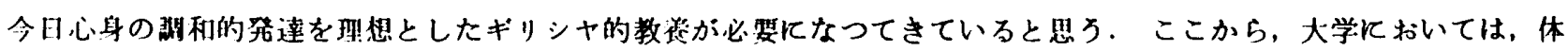

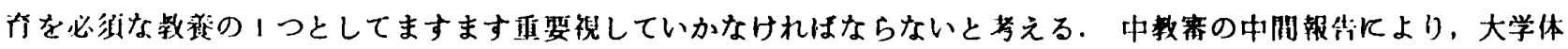

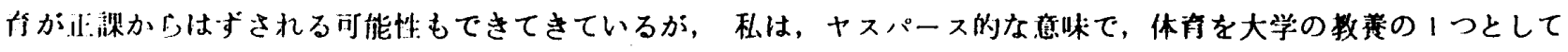

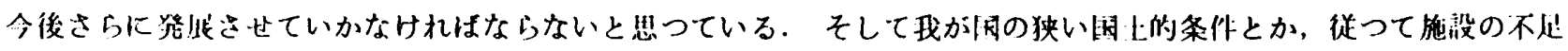

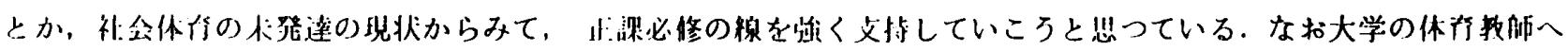

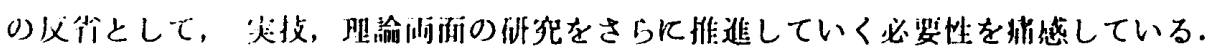

\section{8. 表現体育学について一その発展的・原理的锗問题の措定一}

扣茶の水女子大学 林 粉

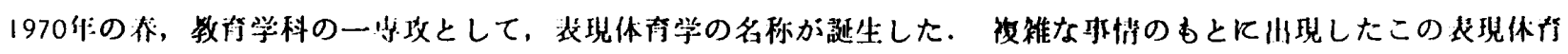

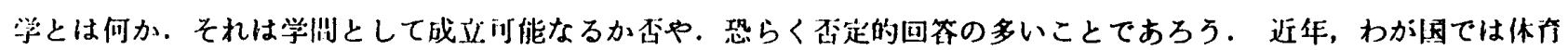

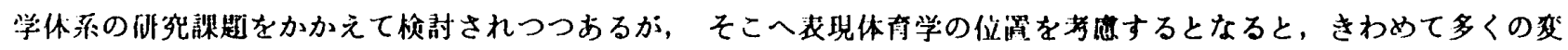

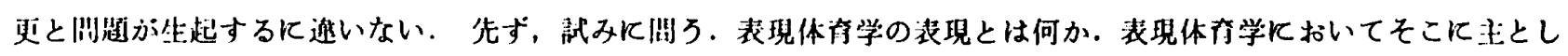

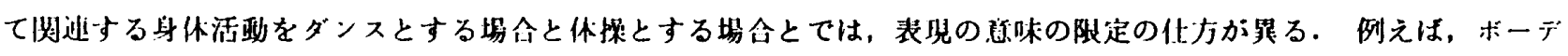

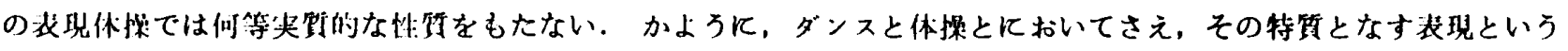

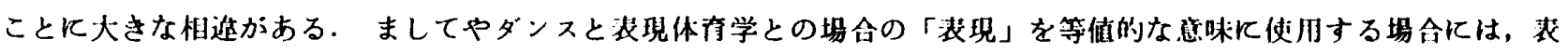

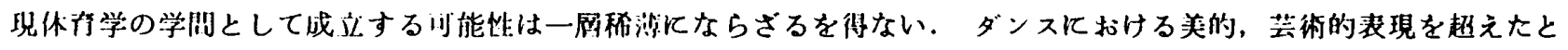

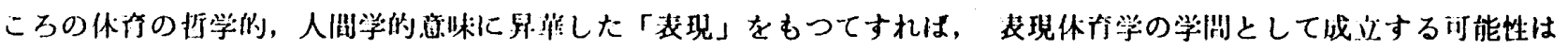

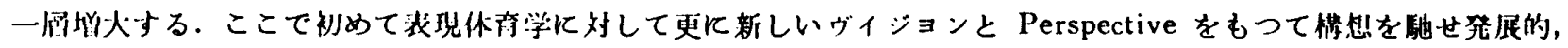

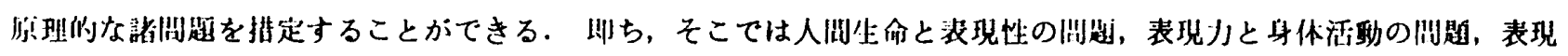

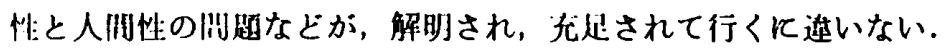

\section{9. 東洋媔学の持色よりみた身体覾の体育暂学「其六」身心一如の「行」の理について}

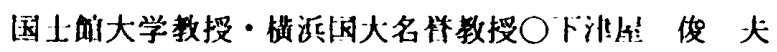

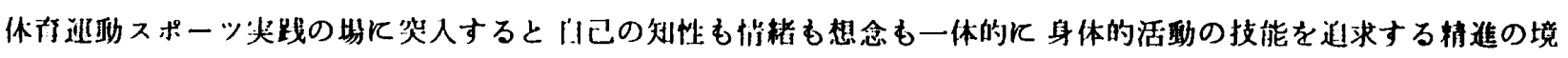

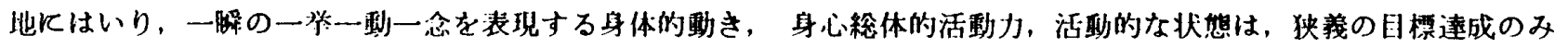

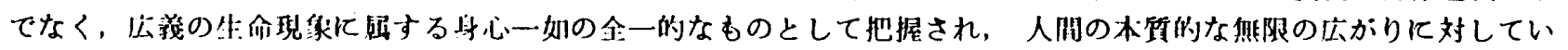

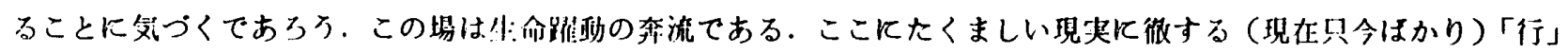
の抑学の意義がある.

プリントの内谷

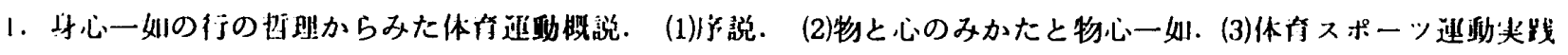
「行」の場の析理.

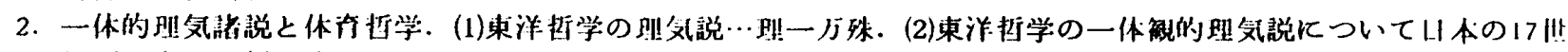

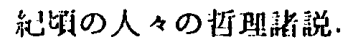

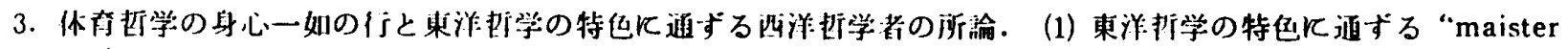

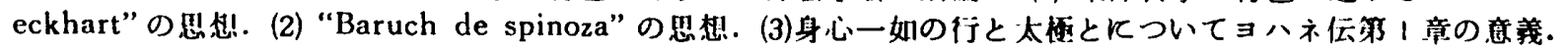

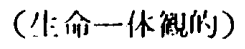

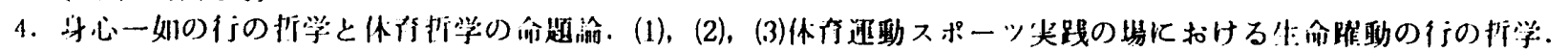

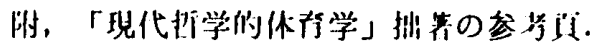

